\title{
Technè
}

La science au service de l'histoire de l'art et de la préservation des biens culturels

48 | 2019

Les couleurs de l'Antique

\section{The experimental reconstruction of the bronze warriors of Riace as part of the Frankfurt "Liebieghaus Polychromy Research Project"}

La reconstitution expérimentale des bronzes de Riace dans le cadre des études sur la polychromie au Liebieghaus de Francfort

\section{Vinzenz Brinkmann and Ulrike Koch-Brinkmann}

\section{OpenEdition}

\section{Journals}

Electronic version

URL: https://journals.openedition.org/techne/2707

DOI: $10.4000 /$ techne.2707

ISSN: 2534-5168

\section{Publisher}

C2RMF

\section{Printed version}

Date of publication: 31 December 2019

Number of pages: 120-132

ISBN: 978-2-17-152831-4

ISSN: 1254-7867

\section{Electronic reference}

Vinzenz Brinkmann and Ulrike Koch-Brinkmann, "The experimental reconstruction of the bronze warriors of Riace as part of the Frankfurt "Liebieghaus Polychromy Research Project"', Technè [Online], 48 | 2019, Online since 01 July 2021, connection on 02 April 2022. URL: http:// journals.openedition.org/techne/2707 ; DOI: https://doi.org/10.4000/techne.2707

\section{(c) () $\odot \ominus$}

La revue Technè. La science au service de l'histoire de l'art et de la préservation des biens culturels est mise à disposition selon les termes de la Licence Creative Commons Attribution - Pas d'Utilisation Commerciale - Pas de Modification 4.0 International. 


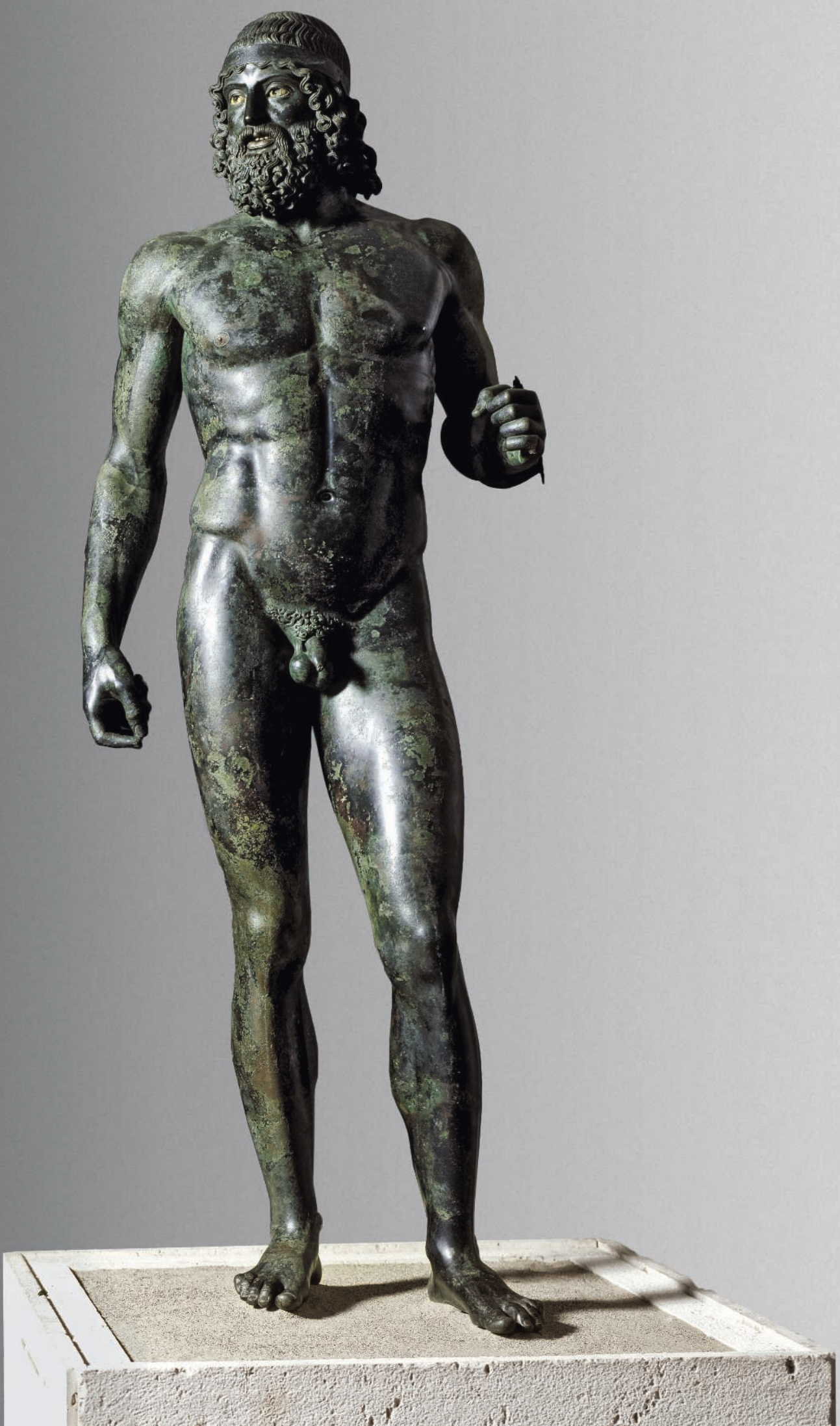

Fig. 1. Riace Warrior A, bronze, 460-440 B.C. (H. 189 cm), National Archaeological Museum, Reggio di Calabria, inv. 12801. (c) The Art Archive/Museo Archeologico Nazionale Reggio Calabria/G. Dagli Orti. 
Vinzenz Brinkmann

Ulrike Koch-Brinkmann
The experimental reconstruction

of the bronze warriors of Riace as part of the Frankfurt "Liebieghaus Polychromy Research Project"
La reconstitution expérimentale des bronzes de Riace dans le cadre des études sur la polychromie au Liebieghaus de Francfort

\begin{abstract}
The contribution describes the experimental reconstruction of the two bronze warriors discovered in 1972 in the sea a few meters off the coast of Riace. The Frankfurt project intends to contribute to the question of the production process, but also to the interpretation of these famous sculptures. On the basis of a 3D scan, a 1:1 bronze replica was recast. Eyes, eyelashes, lips, teeth and nipples, which had been originally made of stones and inlays of copper and silver, were reproduced and, together with a speculative patination and a painting based on linseed oil and asphalt, provide a starting point to discuss issues of the authentic appearance. Meticulous studies of the preserved technical traces on the warriors' heads allow a reconstruction of both lost headgears that eventually provide a strong argument for the identification of both warriors.

Keywords. Riace bronzes, bronze polychromy, artificial patination, experimental reconstruction, Erechtheus, Eumolpos, alopekis.
\end{abstract}

Résumé. Nous décrivons ici la reconstitution expérimentale de deux guerriers en bronze découverts dans la mer en 1972, près du rivage de Riace. Les travaux entrepris à Francfort tentent de contribuer au débat sur les procédés de fabrication de ces célèbres statues, mais aussi sur leur interprétation. Une réplique grandeur nature en bronze a pu être fondue à partir d'une numérisation en 3D. La reproduction des yeux, des cils, des lèvres, des dents et des mamelons, primitivement en pierre et incrustations de cuivre et d'argent, complétée par une patine hypothétique et une peinture à l'huile de lin et au bitume, fournit une base de réflexion sur l'aspect original des bronzes. Un examen méticuleux des traces matérielles décelables sur les têtes des guerriers a permis de reconstituer les deux coiffes disparues, et d'étayer solidement lidentification des personnages.

Mots-clés. Bronzes de Riace, polychromie des bronzes, patine artificielle, reconstitution expérimentale, Érechthéion, Eumolpe, alopekis.
In the following lines, we will briefly report on an archaeological experiment in the field of ancient Greek bronze sculpture - an experiment oriented not strictly towards the recovery of ancient metallurgical processes, but rather towards the recovery of the external appearance of the sculpture $^{1}$. The project, which is part of 40 years of research on Greek sculptural polychromy ${ }^{2}$, aims above all to contribute to a discussion on the issue of polychromy of ancient Greek bronze sculpture ${ }^{3}$, as well as on the question of interpretation ${ }^{4}$. With this in mind, not only the results of scientific research on ancient bronze sculptures, which have been compiled by various research teams worldwide in recent decades, but also the relevant written sources have been taken into account. ${ }^{5}$
In addition to the polychrome appearance, there was an effort to reconstruct the lost elements of the figures (headgear and weapons) on the basis of the preserved technical evidence, in order to be able to offer new arguments for the question of the interpretation of the figures. However, the theoretical analysis of all the bronze surface finishing techniques of past and present times is a prerequisite for the approach of our practical experiment. Richard Hughes ${ }^{6}$, Carol C. Mattusch ${ }^{7}$, Peter C. Bol ${ }^{8}$, Frank Willer ${ }^{9}$, Alessandra Giumlia-Mair ${ }^{10}$, Sophie Descamps-Lequime and Benoît Mille $^{11}$, among others, provide the necessary foundations in their relevant publications.

Once again, the experiment has shown that the technological, aesthetic and narrative qualities of a work of art are inextricably interwoven.

Prof. Dr. Vinzenz Brinkmann, Head of the Department of Antiquities, Liebieghaus Skulpturensammlung, Frankfurt am Main 


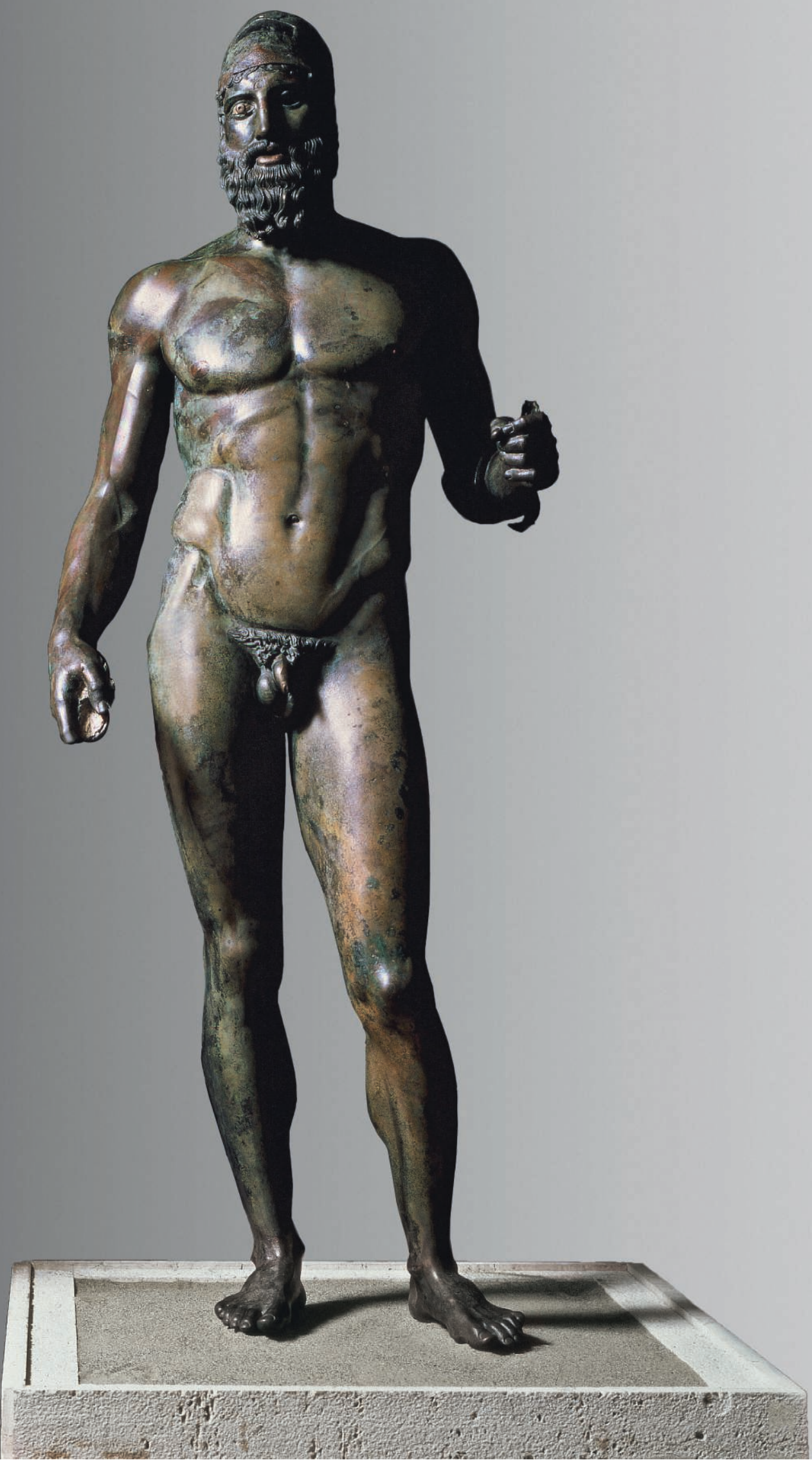

Fig. 2. Riace Warrior B, bronze, 460-440 B.C. (H. 198 cm), National Archaeological Museum, Reggio di Calabria, inv. 12802. (c) The Art Archive/Museo Archeologico Nazionale Reggio Calabria/G. Dagli Orti. 


\section{The 3D experimental reconstruction of Riace $A$ and $B$}

The two Greek bronze statues of Riace (fig. 1-2) ${ }^{12}$, dated to the 5 th century B.C. ${ }^{13}$ and found in the sea off Riace in $1972^{14}$, were captured three-dimensionally and with high precision by Lorenzo Campana (forensic imaging) with the equipment (Atos) of the Braunschweig company GOM in structured light. After processing the data (Creabis company), the moulds were printed by Voxeljet (polymethyl methacrylate impregnated with paraffin). The casting (fig. 3), chasing and artificial patination (fig. 4), executed by Toni Silvestri and Recep Sarip, took place in the Kunstgiesserei Strassacker ${ }^{15}$. The goldsmith's work was carried out by the Frankfurt artist Kristina Balzer, the stone cutting by Manfred Wild ${ }^{16}$ in Idar-Oberstein (fig. 5). The colour design with asphalt varnish and pigment was in the hands of the archaeologist Ulrike KochBrinkmann (fig. 6), while the gilding and silvering was carried out by the restorers Petra Bausch and Stephanie Forbach.

After the Liebieghaus Polychromy Research Project was able to achieve the complete casting of the bronze warrior Riace A in 2012-2015 (fig. 7), the figure known as Riace B was then launched (2014-2016) ${ }^{17}$.

Due to the sculptural elaboration of the head hair and hair band, it could be shown in the experiment that Riace A undoubtedly had put on a so-called Corinthian helmet only loosely on the skull. Also, due to the position of the left arm and the shaping of the right hand, not only shields (round shield for Riace A, pelta for Riace B), but also weapons (Riace A: lance, Riace B: battle axe) must be added ${ }^{18}$. For the recovery of the lost headgear of Riace $B$, the initial situation was much more complex. However, the technical traces - this became clear after detailed examination - have a high significance.

Our experiment shows that the addition of a foxskin cap can explain all the technical features on the forehead, top and back of the Riace B statue. The strongest indication is a bronze sheet soldered to the nape of the neck (fig. 8). To judge from the unfinished aspect of the surface, it was not intended to be seen, and later it got partly broken off by force.
Over this mounting aid, the separately worked foxtail was slipped and thus fastened.

The unnatural conical shape of the upper part of the skull was used to adjust the tight-fitting cap of the foxskin cap. This device could also imitate the soft and flexible character of the cap in metal. A dotted gable-shaped copper sheet above the forehead represents the leather sweatband, which also served as a drawstring (fig. 9). The continuation of this drawstring has been preserved behind the right ear in the form of a dotted copper sheet. A further small rectangular dotted copper sheet far above the forehead served as a leather backing for the eye sockets of the fox's head and thus 


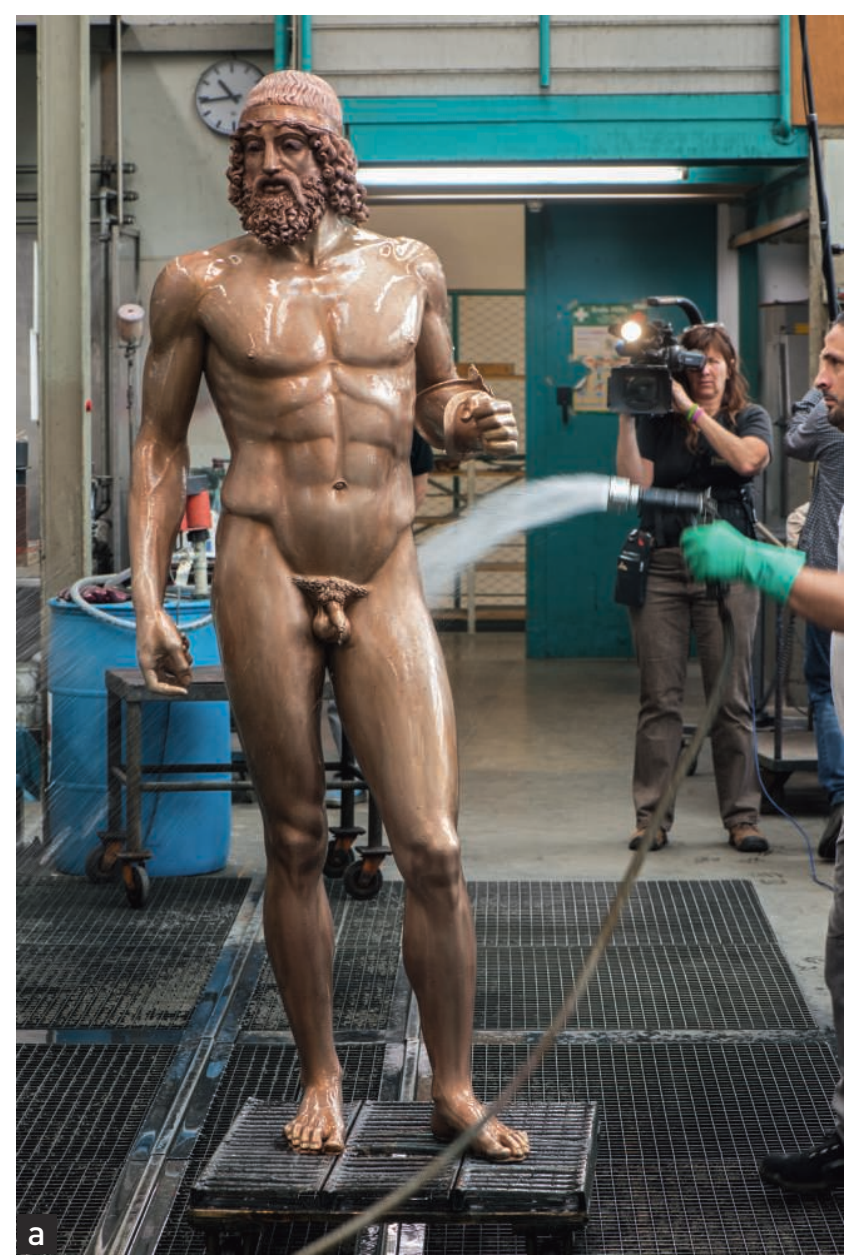

Fig. $4 a-b$. Patination of the bronze cast, reconstruction of Riace A. (C) V. Brinkmann.

prevented a sight onto the raw surface of the skull. The reproduction and casting of the individual elements of the fur cap made it clear that the transition from the finished to the unfinished surfaces of the skull was also precisely adapted to the design and position of the headgear (fig. 10).

Fox fur caps are the typical headgear of the Thracians living in northern Greece. In Greek art, members of this huge ethnic group are characterized by these alopekis, but also by short riding coats and embades (fur boots). Occasionally, as for example on the frieze of the Athenian Parthenon, Athenian citizens do also appear dressed up in the Thracian costume.

The Greek myth tells the story of the relations between Greeks and Thracians in many ways. Famous were the Thracian singer Orpheus or the mythological kings of Thrace Lykurgos, Diomedes, Rhesos and Eumolpos.

Riace B must be interpreted as a Thracian hero of the Greek mythology because of his foxskin cap and nudity. Since he was shown in battle with a Greek hero (Riace A with Greek helmet), it can only be the Thracian king Eumolpos, son of Poseidon and founder of the mysteries in Eleusis, who was defeated in the fight against the Athenian king Erechtheus. All other male Thracian persons of the ancient mythology are

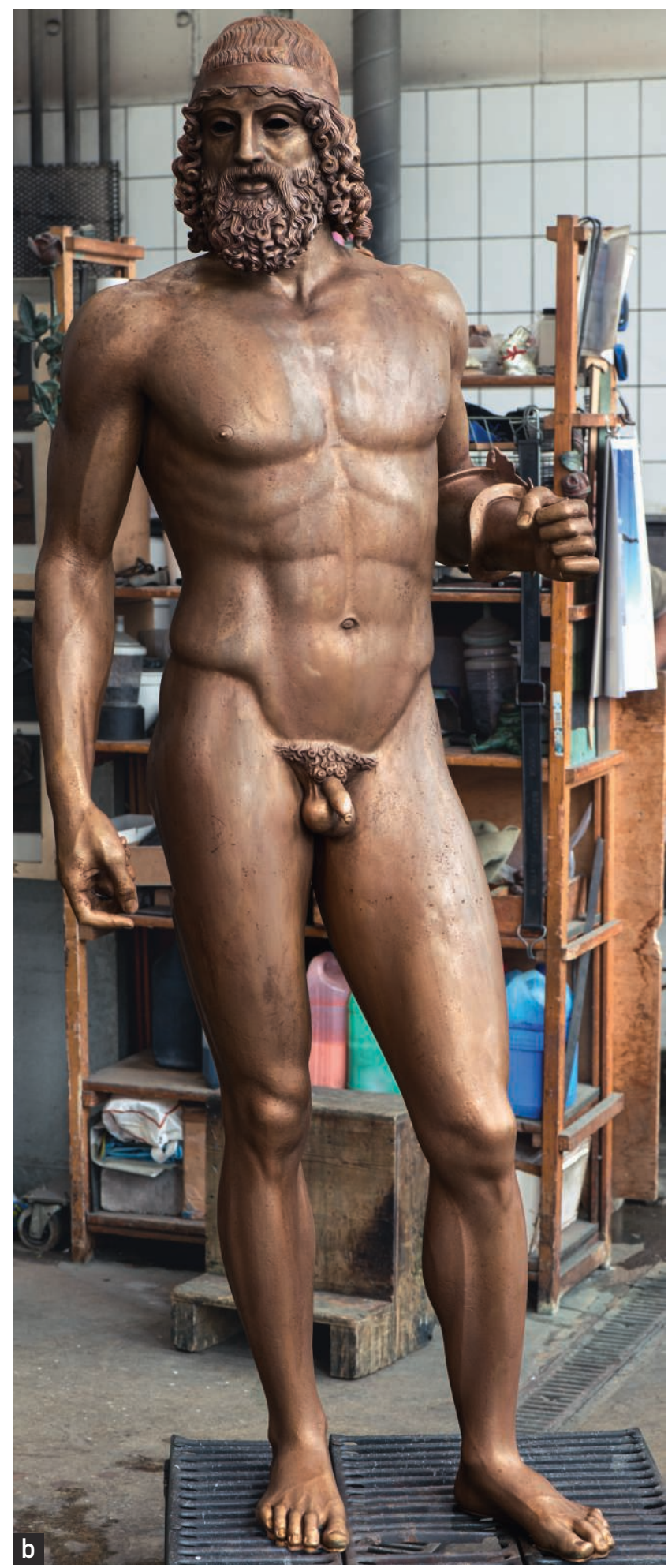




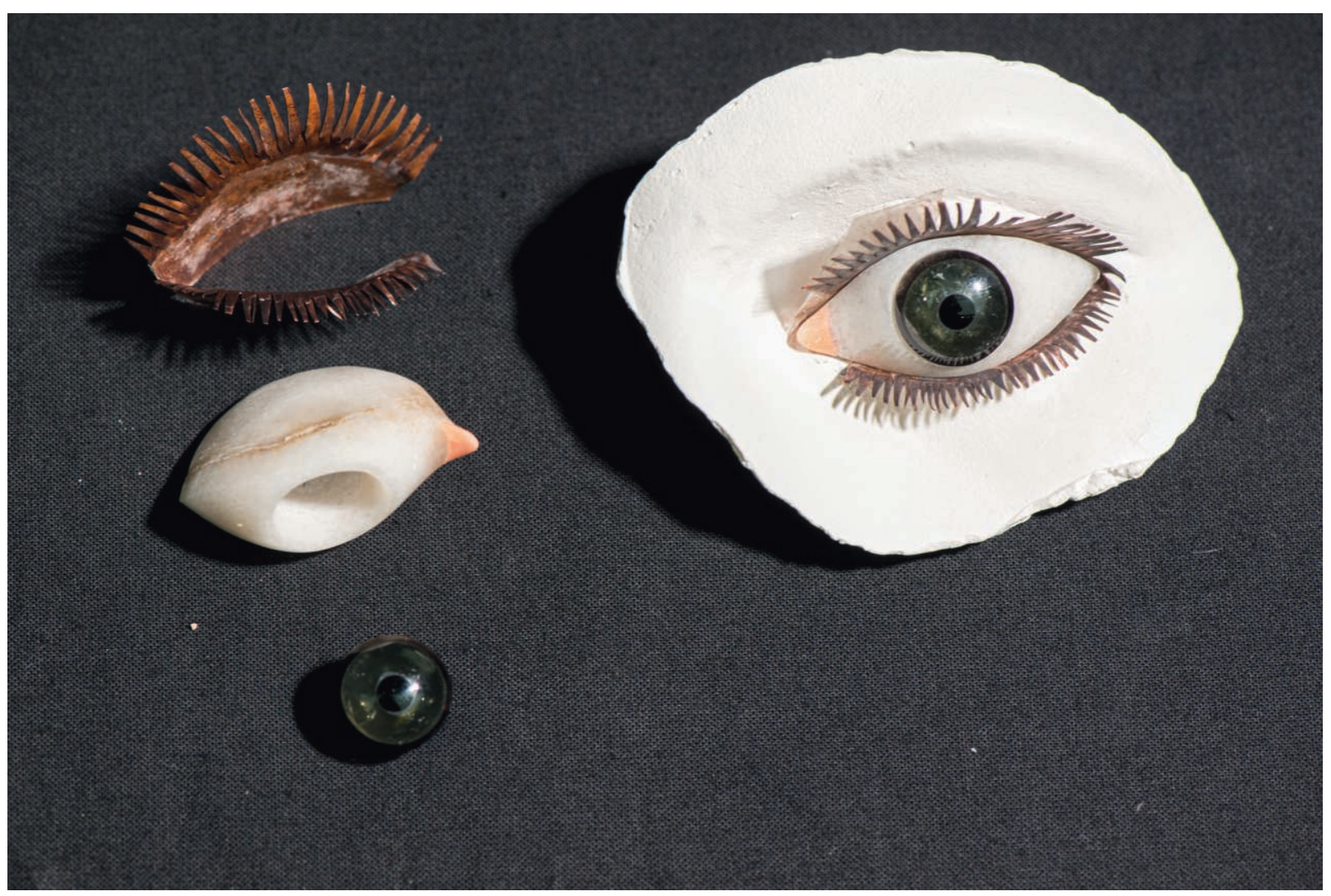

Fig. 5. Eye of Riace B, consisting of inlays of five different stones: a cylindrical black capsule held a light-shaded iris with a black pupil inlaid in white stone; a reddish stone represented the caruncle. (C) V. Brinkmann.

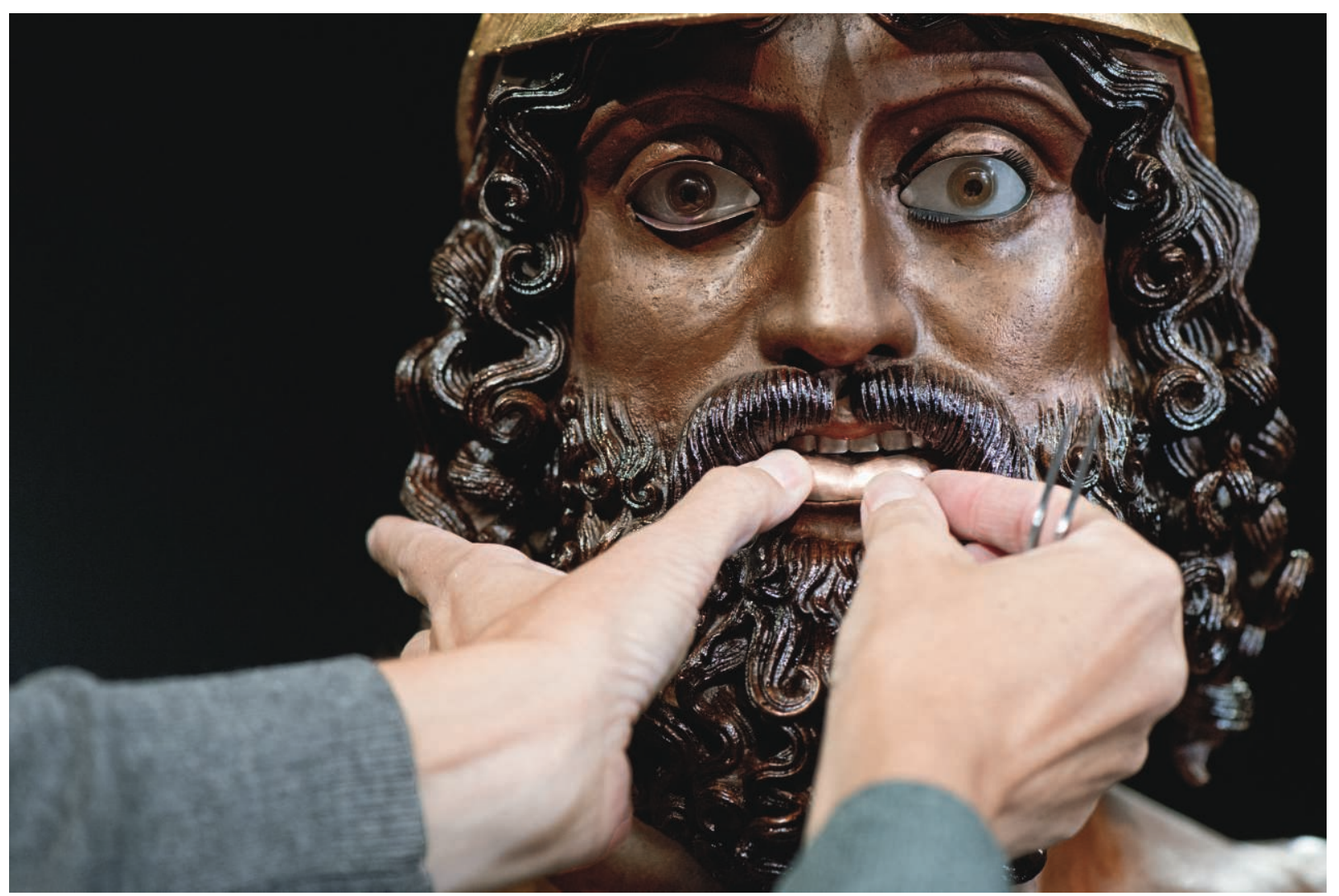

Fig. 6. Experimental reconstruction of Riace A, fresh application of asphalt lacquer, adjustment of copper sheets for lips. (c) V. Brinkmann. 


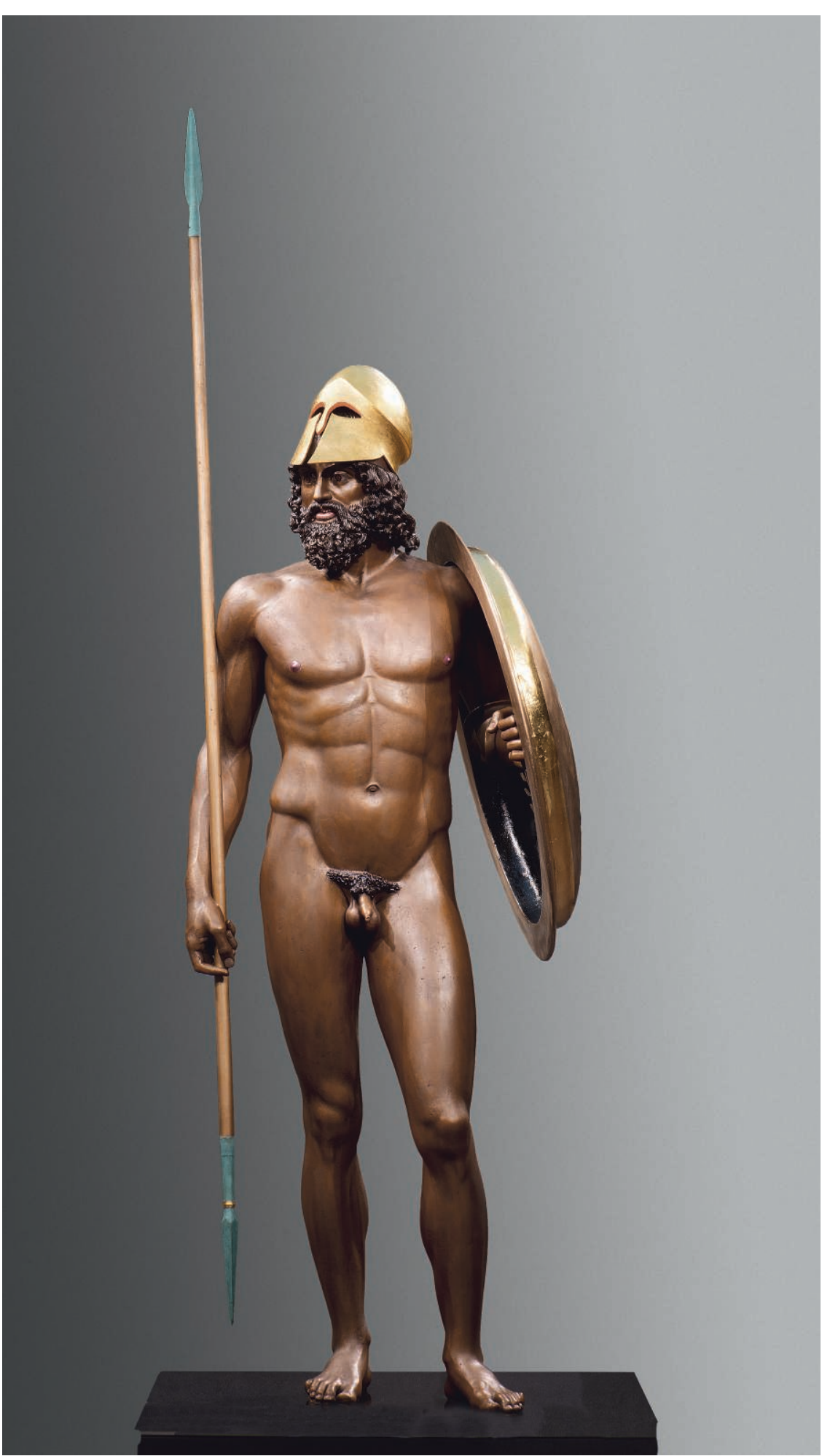

Fig. 7. Reconstruction of Riace Warrior A, bronze, 2015 (H. 209 cm), Liebieghaus Skulpturensammlung (Polychromy Research Project), Frankfurt/National Archaeological Museum, Reggio di Calabria, LG 133. (C Liebieghaus Skulpturensammlung Frankfurt/Rühl \& Bormann. excluded, as they are never portrayed in an open battle with a Greek hero.

From the ancient traveller author Pausanias, we learn that a group of sculptures showing Erechtheus and Eumolpos immediately before their battle had been placed on the Athenian Acropolis $^{19}$. Our research leads us to the compelling conclusion that the originals of this group have been preserved in the two bronze warriors from Riace $^{20}$.

From ancient literature, we learn that Thracians were imagined to be blue-eyed $^{21}$, red-haired and light-skinned $^{22}$. We made this idea clear by giving the Thracian Eumolpos (Riace B) a light incarnate, reddish hair and blue-green stone eyes ${ }^{23}$. These three colour values are not documented on the statue itself, but were deduced by us according to the written sources (fig. 11).

The color values of the skin and the hair were obtained in the experiment in two separate steps. At first, the casters of the foundry Strassacker achieved a light, brownish basic tone by treating the fresh bronze with liver of sulphur (potassium sulphide) and copper nitrate. Later, the skin was coated several times with a thin solution of asphalt varnish, linseed oil and indigo. Accordingly, hair and beard received a reddish patina in the foundry through the application of potassium permanganate, before being coated several times with a thin solution of asphalt varnish, linseed oil and madder ${ }^{24}$.

Due to the scientific evidence of sulphur residues in the surface of numerous historical bronzes, both from underwater and terrestrial finds, it has often been considered that an intentional patination with a sulphurcontaining agent was already carried out in Greek and Roman Antiquity ${ }^{25}$. Our experiment has also clearly shown by direct observation that fresh bronze or fresh copper oxidizes quickly and uncontrollably and therefore requires patination with chemical agents immediately after casting and chasing. 


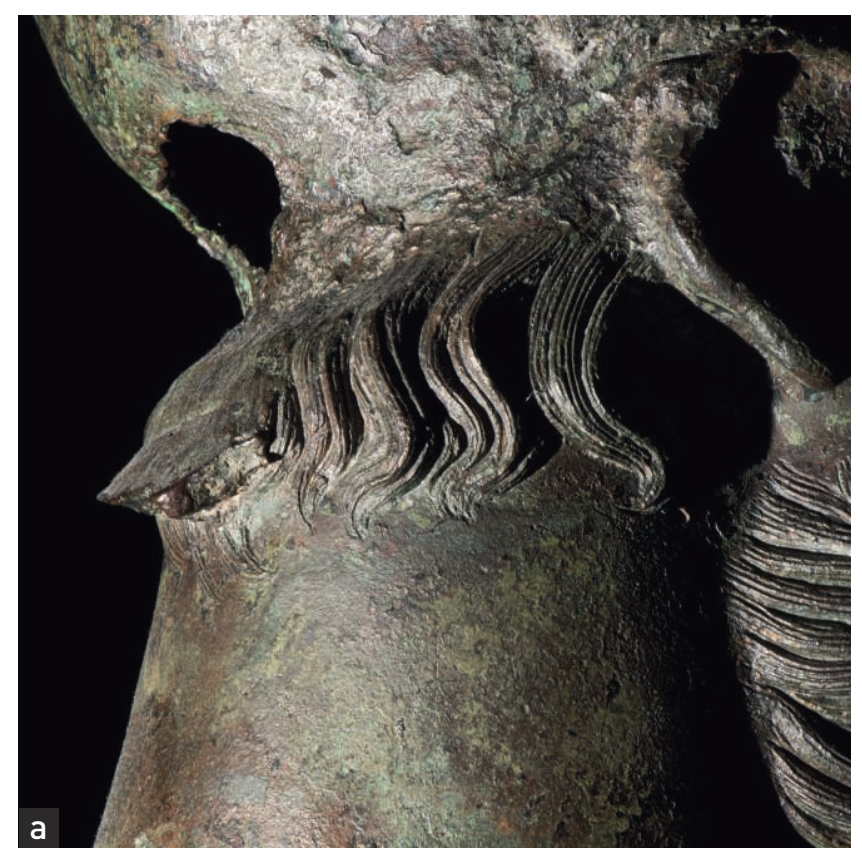

Fig. $8 a$ - $b$. Bronze plate soldered to Riace B's neck. (C) V. Brinkmann.

\section{Bitumen and oil}

"If you scratch bronze, it gets a layer of verdigris faster,... unless you coat it with oil. And the oil itself, it is said, is best preserved in liquid pitch." (Pliny, NH 34.99 - trans. V. Brinkmann).

Numerous Greek and Roman written sources mention the application of asphalt/bitumen (among other substances in connection with oil ${ }^{26}$ ) on bronze works ${ }^{27}$, whereby it also becomes clear that asphalt was used not only because of its preservative quality but also as a means of colour design ${ }^{28}$. Of particular interest is the information provided by Pliny, which states that oil is preserved by mixing it with bitumen.

Our experiment has also shown that asphalt varnish mixed with linseed oil and pigment can be used exceptionally well as a colourant. This is due on the one hand to the ideal viscosity and on the other hand to the transparency of the material. In addition, the transparency and thus the brightness of the solution can be controlled by the degree of dilution.

\section{Alloy, patina and colour}

"If you add lead to the Cypriot copper, you will get the purple color of the toga praetexta on the statues." (Pliny, NH 34.98 - trans. V. Brinkmann).

Studies and experiments that explore the interdependence between alloy mixing ratios ${ }^{29}$ (lead, tin, iron, gold, arsenic, nickel and copper) and intentional patination have been carried out by Alessandra Giumlia-Mair (based on the alchemistic writings of Zosimos of Panopolis) ${ }^{30}$ and most recently by a research project at the university of Aix-en-

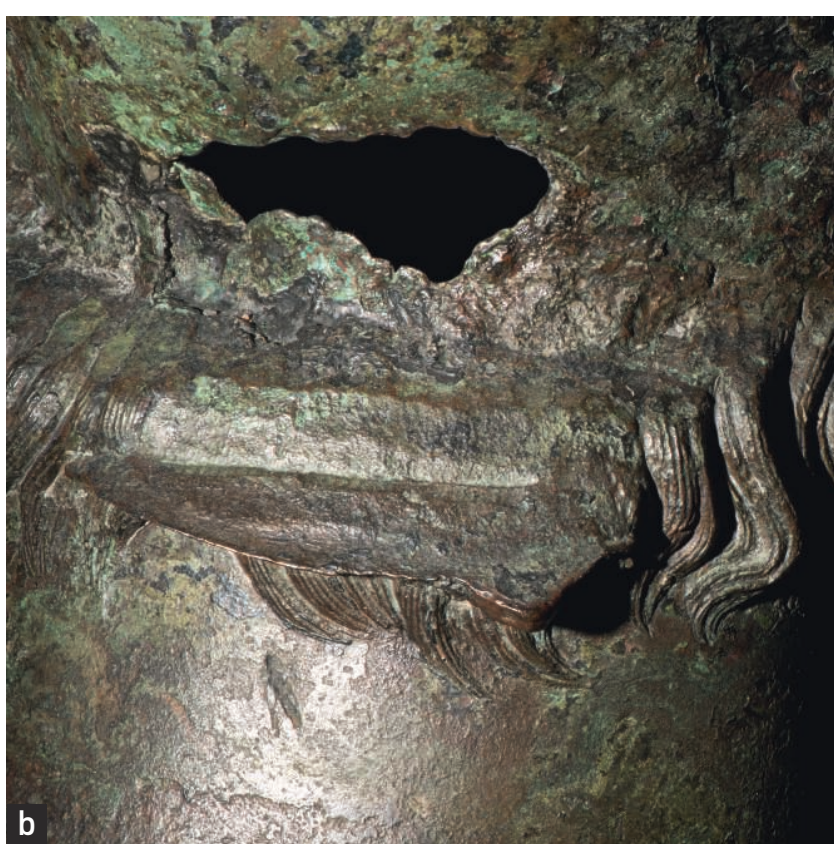

127

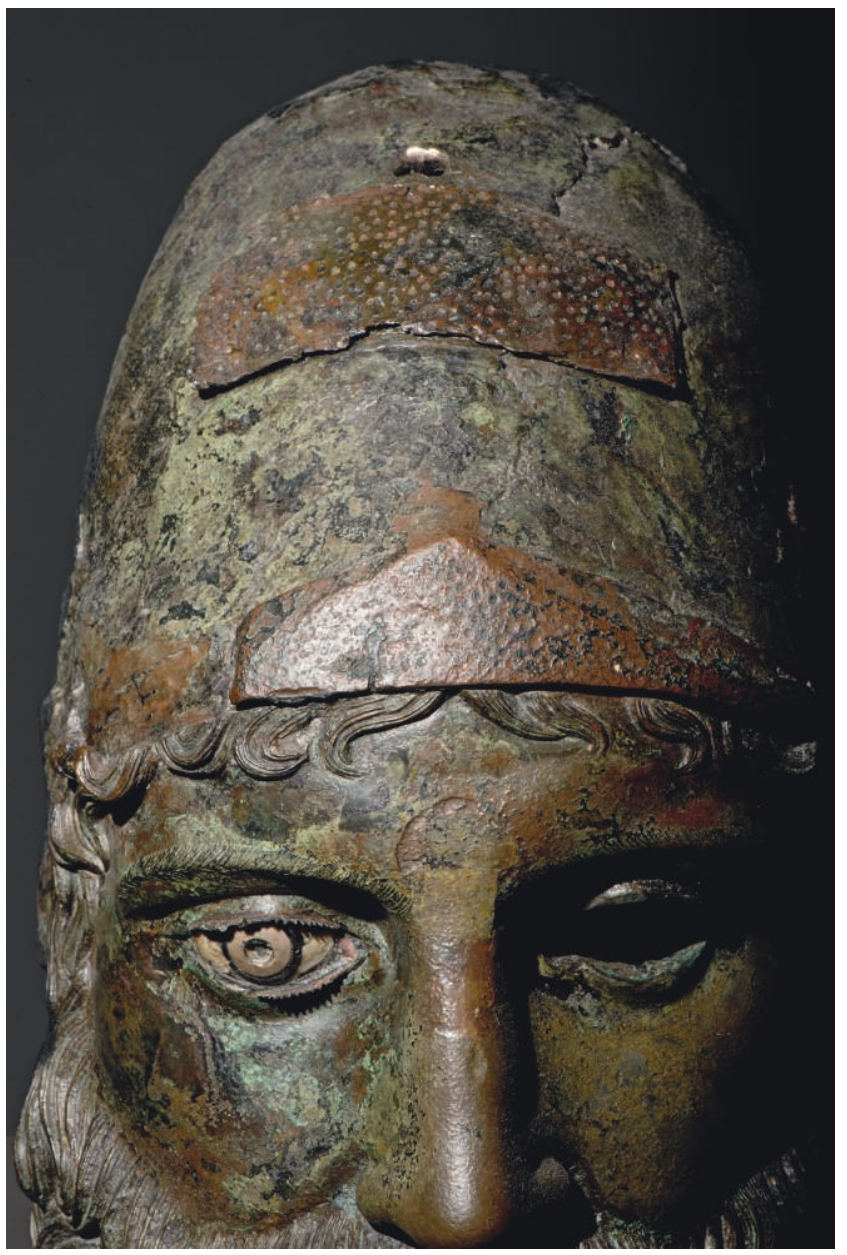

Fig. 9. The forehead of Riace B, inlaid with a rectangular and a triangular sheet of punctured copper; also featuring a square recess. (C) V. Brinkmann. 


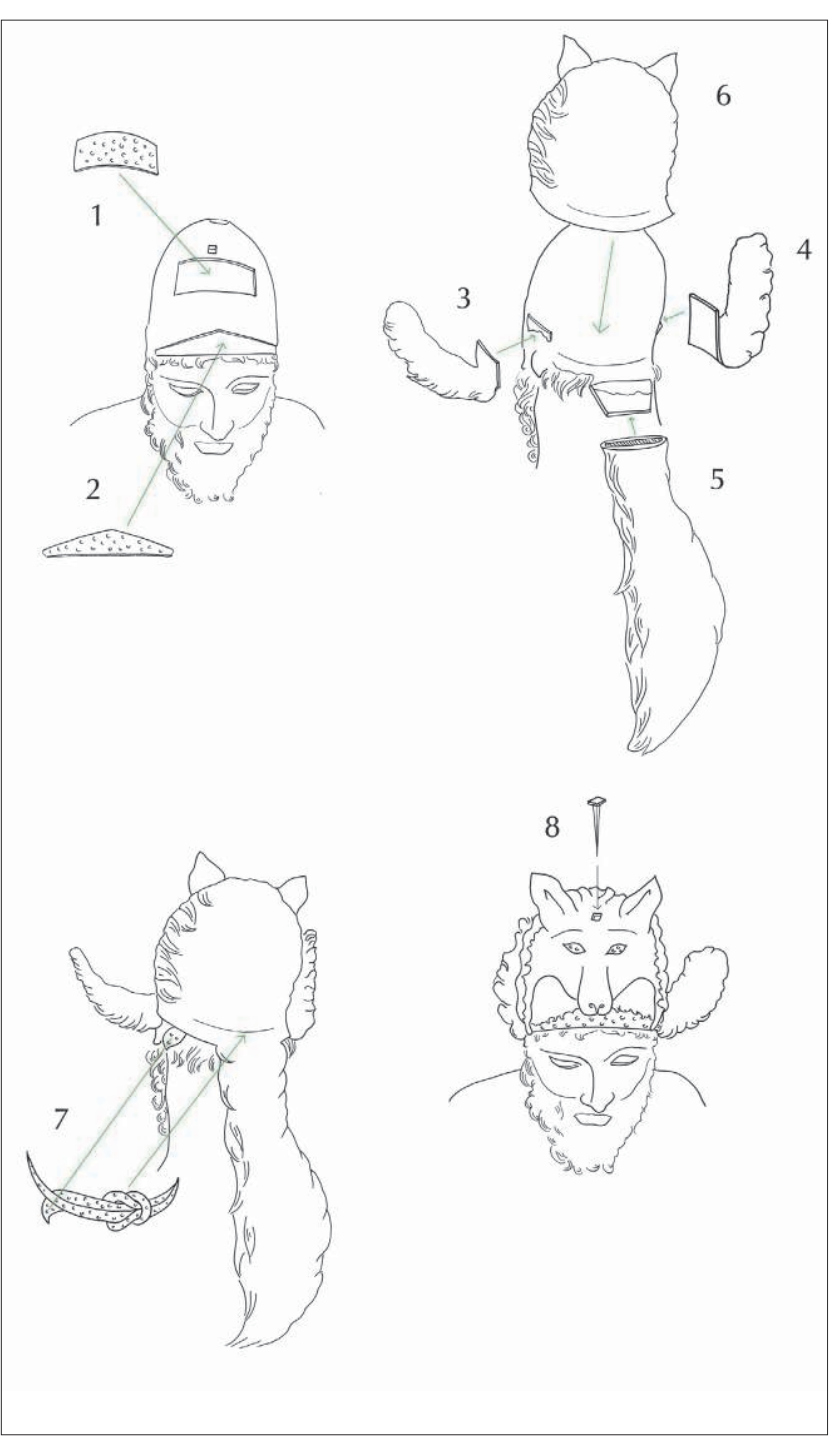

Fig. 10. The individual elements of Riace B's alopekis in order of assembly. Drawing: Ulrike Koch-Brinkmann.

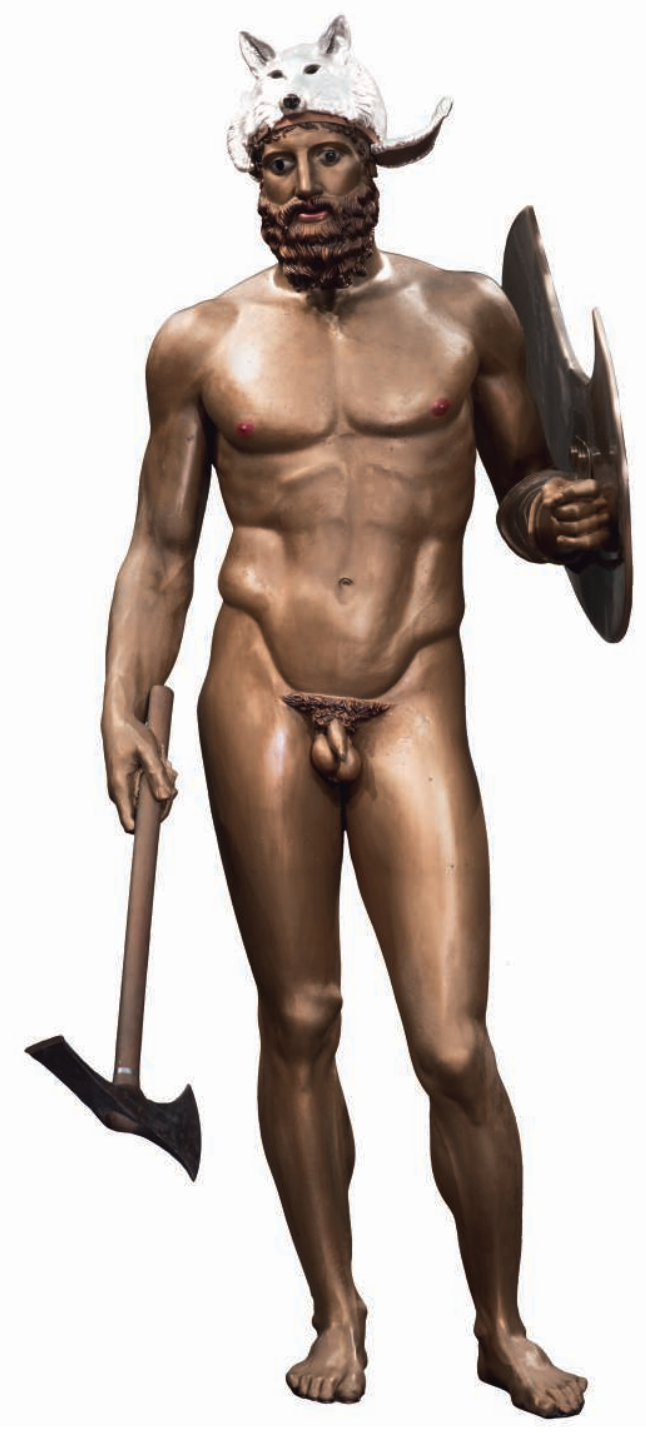

Fig. 11. Reconstruction of Riace Warrior B, bronze, 2016 (H. 209 cm), Liebieghaus Skulpturensammlung (Polychromy Research Project), Frankfurt/National Archaeological Museum, Reggio di Calabria, DEP. 65. (C) Liebieghaus Skulpturensammlung Frankfurt/Rühl \& Bormann.

The colour difference between the cleaned untreated surfaces of the castings and the bronze alloy of the entire sculpture is minimal. The cross section of the castings, however, reveals under the scanning electron microscope that the lead forms cluster structures within the alloy during the cooling process, which are particularly concentrated near the surfaces. If the lead concentration in the alloy is higher than $20 \%$, the casting quality suffers and craters form on the surface as the lead melts out. Only when treated with sulfur liver, a special effect of this lead bronze compared to a normal bronze alloy can be observed: the surface turns violet blue to purple.

Of course, analogous differentiations cannot be excluded for the bronze warriors from Riace. Perhaps future investigations will shed further light on this aspect ${ }^{34}$. 


\section{Excursus: the use of silver for the colouring of bronze sculptures}

IACE A's upper row of teeth, cast in bronze, has a silver plate placed on it that accurately reproduces the shape of the teeth (fig. 12). In analogy to our observations on the lead bronze of the hematoma on the boxer, the question arises whether the use of this silver plate was nothing but preparation for a special colour effect. Here the application of transparent lustre colours on a shiny metal base would be suggested in order to achieve the lifelike character of the whitish tooth enamel.

Riace B was reconstructed, as explained above, with a foxskin cap based on technical evidence. Since the cap itself was torn off by force, as the large hole in the back of the head suggests, it must have been cast from another, probably more valuable metal, perhaps silver. Since the portrayed person obviously represents a Thracian king, he deserves the royal silver fox as an attribute. In our experiment, the cap was silver plated. It is not to be excluded therefore that the material character of the fur was carried out by fine painting, presumably in lustre painting technique (see below). An ancient written source suggests that in Greek Antiquity, specialists were consulted who mastered the deceptively genuine reproduction of animal fur ${ }^{35}$.

Our experiment has shown that darker colours in the red, brown and black spectrum can be achieved by artificial patination - often in combination with the colour of the bitumen. Of course, medium to dark tones of blue and green can also be produced by chemical treatment ${ }^{36}$ due to the naturally high copper content of the bronze sculptures. Light shades, from white to ivory or to apricot, however, cannot be achieved by artificial patination of the bronze. Due to the numerous mentions of mimetic effects in ancient literature, which celebrates the realism of ancient bronze sculptures, we must assume a colouring that follows nature, thus demanding a realistic skin tone, real-looking robes and weapons. The colouring of female skin or whitish garments can therefore not have been produced by patination, but in another way. Various solutions are available:

1) Application of white or whitish pigments, bound in tempera or bitumen

The simple colour application of a pigment bound by a binding agent is rather to be excluded, since in this technique, the aesthetic charms of the metal sculpture are not employed.

2) Kaolin ground

An Egyptian bronze head of Hathor in the Athens National Museum, but also numerous Chinese bronze sculptures from Xi'an were partially or completely coated with a compact layer of kaolin, which served as a primer, e.g. for gilding or paint application. As this kaolin base has

Fig. 12. Macro-photograph showing Riace A's solid copper lips and silver teeth. (C) V. Brinkmann. a thickness of a few millimetres, the layer was already planned as a stepped layer by the bronze sculptors.

3) Lustre colours on silver

An inscription from Athens ${ }^{37}$, which most probably contains the accounting of the production of the colossal and stunningly lifelike bronze sculpture of Athena Promachos by the sculptor Phidias ${ }^{38}$, which took about nine years, lists a large quantity of raw silver (argyrion asemnon), which was explicitly used for the coloring (es poikilian) of the statue. This epigraphic evidence could suggest inlays of ornament and the like, but also the application of lustre colours on silver ${ }^{39}$. In this case, the naked parts of the youthful female body as well as the scales of the aegis were the most important elements, which Niketas Choniatès still describes as multi-coloured ${ }^{40}$, silver-plated by amalgam or the like ${ }^{41}$, or cast as separate workpieces in solid silver. Painting with semi-transparent colour lacquers on highly reflective precious metal surfaces is richly documented for post-antique European art and one can at least speculate whether similar techniques were already known in Egyptian and Greek-Roman Antiquity ${ }^{42}$.

In lustre colour, a shimmering, bright female complexion can be achieved precisely by applying glazes, e.g. in a delicate apricot colour, as has been demonstrated several times for the female skin of the marble sculpture ${ }^{43}$. The lustre and play of light of silk fabrics could also be achieved using a suitably designed lustre technique, depicted on silver, gold or similar.

The possible use of transparent colours for the polychromy of bronze sculpture should at least be considered in the interpretation of ancient written sources and in future scientific investigations.

In the eighth (?) year of the construction of Athena's 30 -foot bronze statue, a larger amount of wax was apparently consumed, according to the account document ${ }^{44}$. This item can in turn be directly linked to the cleaning process of the surfaces silvered (or gilded) by fire. Even today, pure beeswax (also alum, vitriol, borax) is used to remove remaining residues of mercury or copper from the precious metal - once again under the influence of heat ${ }^{45}$. Only after this step and subsequent smoothing with brass wire brushes, agate or polished hematite, the precious metal coating regains its optimum natural shine.

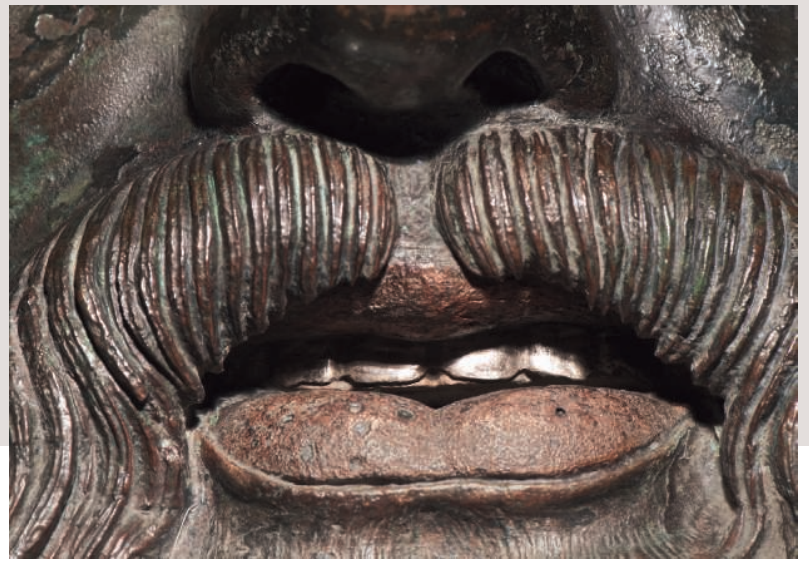




\section{Notes}

1. See the studies of S. DescampsLequime, 2006.

2. Brinkmann, 1987 ; Brinkmann, 1994; Brinkmann, 2003; Brinkmann, Dreyfus, Koch-Brinkmann, 2017 (with further bibliography). Brinkmann, KochBrinkmann (eds.), Bunte Götter-Golden Edition. Die Farben der Antike, exhibition catalogue Liebieghaus Skulpturensammlung Frankfurt am Main, 2020 (with further bibliography); Michael Siebler, Die Farben der Muse. Ein Frankfurter Forschungsprojekt zur antiken Statuenpolychromie, Frankfurt am Main, 2020.

3. See Inscriptiones Graecae $\mathrm{I}^{3}, 435$, line 79 (Der Neue Overbeck 870), where the polychromy of the Athena Promachos, produced by Phidias, is named "poikilia".

4. For further details, see Brinkmann,

Koch-Brinkmann, 2018a.

5. Muller-Dufeu, 2006; Henke, in print

6. Hughes, Rowe, 1991; Hughes, 1993.

7. Mattusch, 1996; Mattusch, The Victorious Youth, 1997.

8. Bol, 1985

9. Willer, 1994

10. Craddock, Giumlia-Mair, 1993.

11. Descamps-Lequime, 2006

Descamps-Lequime, Mille (dir.), 2017.

12. Giuliano, 1981; Guzzo, 1981;

Triches, 1984; Stefano Marriottini, "Il

rinvenimento dei Bronzi di Riace: la testimonianza dello scopritore" in Maurizio Paoletti (ed.), Relitti, porti e rotte nel Mediterraneo, 2009, p. 89-90.

13. Maurizio Paoletti, "Le Statue", in Paoletti, Settis, 2015, p. IX-XII. Using the C14 method, the organic inclusions in the cast cores of the two bronzes were measured and dated by L. Calcagnile and G. Quarta of the Centro di Datazione e Diagnostica at the University of Salento: Riace A: 512-400 B.C.; Riace B: $510-398$ B.C. Thus the dating is identical and there is no scientific indication of a different time of production. However, a more precise dating within this period of Antiquity is, in principle, unfortunately not possible with the radiocarbon method $(G$.

Quarta, L. Calcagnile, M. Vidale,

"Integrating non-destructive ion beam analysis methods and accelerator mass spectrometry radiocarbon dating for the study of ancient bronze statues", Radiocarbon, vol. 54, no. 3-4, 2012, p. 801-812; L.

Calcagnile, "Tecniche nucleari di analisi e datazione dei beni culturali con l'acceleratore tandetron del CEDAD [Centro di Datazione e Diagnostica, Dipartimento di Ingegneria dell'Innovazione, Università del Salento, Italia]", in S. Lorusso (ed.), Conservation Science in Cultural Heritage, 2013, p. 120-122)

14. The site, which is located on one of the most important sea routes of Antiquity and the Middle Ages, linking the western and eastern Mediterranean, does not provide any useful information about the original location of the bronzes. Since no remains of a shipwreck were found, no information is available on the date and conditions of the accident. Therefore, countless scenarios are conceivable.
(Interesting in this context is the base in Pergamon, on which statues of Myron were newly erected in a proto-museal context (Der Neue Overbeck 749; Inschriften von Pergamon 136). The Riace bronzes may also have been removed from a secondary exhibition by art lovers or scrap dealers. See MMD 725/Der Neue Overbeck 761, Prokop, De bellis 8,21,14 for the repositioning of the famous cow of Myron at the Forum Pacis in Rome.)

15. A bronze alloy with $90 \%$ copper content was used for the casting by the Strassacker foundry (Süssen). cf. Melucco Vaccaro, de Palma, de Micheli, Vidale, 2003, Part 1, p. 185-219.

16. https://www.spiegel.de/karriere/ edelsteinkuenstler-aus-idar-obersteinbeliefert-koenigshaeuser-a-912099.html

17. The reconstruction of Riace A was first displayed in the inaugural exhibition of the new Prada Foundation in Milan in 2015. Both reconstructions were shown in the Frankfurt Liebieghaus sculpture collection exhibition "Athens: The Triumph of Imagery" in 2016 and in the "Gods in Color" show at the San Francisco Legion of Honor in 2017-2018. See Brinkmann, 2015;

Brinkmann, Koch-Brinkmann, 2016; Brinkmann, Koch-Brinkmann, 2017.

18. Brinkmann, Koch-Brinkmann 2018a, p. 19

19. Pausanias, 1.27.4. “... large bronze figures of men facing each other for a fight, one of whom they call Erechtheus, the other Eumolpos..."

20. Manolis Korres proposed to identify elements of a statue base preserved on the Athens Acropolis as the base of the group mentioned at Pausanias (Manolis Korres, Study for the Restoration of the Parthenon, vol. 4 (1974), p. 86-87, 124). However, the base blocks carried two warriors in the wide lunge step according to the mounting holes. This action is incompatible with the choice of words of Pausanias, who uses the verb diistemi for Erechtheus and Eumolpos.

Pausanias mentions elsewhere (9.30.1=MMD 713/Der Neue Overbeck 731) a statue of Erechtheus by Myron in Athens. This second mention needs not refer to the Erechtheus-Eumolpos group of the Acropolis, since at least a second statue of Erechtheus (as Eponymous Heros) was placed on the Athenian Agora. See also MMD 713/Der Neue Overbeck 731, where the Erechtheus statue from Pausanias 9,30,1 is equated with Erechtheus of the Athenian Agora at Pausanias 1.5.2. Note, on the other hand, that Giorgios Dontas (Dontas, 1984, p. 277-296) argues in detail and in a wellfounded manner that Riace A comes from Myron.

21. See the blue eyes of Athena in the Athenian Hephaisteion. Pausanias explains that the sea god Poseidon is father of Athena (Paus. 1.14.6)

22. Xenophanes, fragment B16

(Clemens of Alexandria Str. VII 22 p. 841 P.): "Thus the Ethiopians imagine their gods dark-skinned, the Thracians blue-eyed and red-haired."

23. Formigli, 2013. See the stone eyes of the gold-ivory statue of Athena by Phidias:
Platon, Hippias major 290a-c (MMD 823/Der Neue Overbeck 895).

24. Craddock, Giumlia-Mair, 1993

25. Hughes, 1993; Born, 1993.

26. This must mean a drying oil such as linseed oil. Olive oil, as proposed by Formigli, 2013, p. 291, is a non-drying oil and thus remains for years a lubricating dust/and dirt trap.

27. Pliny, NH 34.99 "Aere extersa robiginem celerius trahunt, ..., nisi oleo perunguantur. servari ea optime in liquida pice tradunt"; Descamps-Lequime, 2006, p. 83 .

28. Pliny, NH 34.15: "The ancients stained their statues with bitumen, which makes it the more remarkable that they were afterwards fond of covering them with gold" (trans. John Bostock); compare Pausanias 1.15.4: "Here [Stoa Poikile, Athens] are dedicated brazen shields, ..., smeared with pitch lest they should be worn by age and rust, ..." (trans. William Henry Samuel Jones).

29. Compare the description of the different bronze alloys (mixtura), in Pliny, NH 34.94-98.

30. Giumlia-Mair, 2002

31. J. Devogelaere, The Colour Palette of Antique Bronzes: An Experimental Archaeology Project, Exarc 2017,2 (https://exarc.net/ issue-2017-2/ea/colour-palette-antiquebronzes-experimental-archaeology-project).

32. Brinkmann, Koch-Brinkmann, 2018b. Colacicchi Alessandri, Ferretti, 2018 Orazi et al., 2018. Orazi et al., 2019.

33. Pliny, NH 34,98: "Cyprio si addatur plumpum, colos purpurae fit in statuarum praetextis."

34. Descamps-Lequime, 2006, p. 85-92, brings together very vividly traditions and studies of black bronze in Mycenaean and historical Greek-Roman times. The examples show that the dark, dark blue to black hue usually appears as a component in a polychrome colour scheme. Clemens of Alexandria reports that a bronze Serapis statue had a very dark, black-blue colour (Protreptikos 4.48.42; Muller-Dufeu, 2006, p. 95). The accentuation proves the fact that this dark skin (?) color was considered unusual. Serapis is a Ptolemaic divine figure that represents a fusion of Osiris and the Apis bull. In fact, Apis is black in the Pharaonic tradition, while Osiris has green, white or black skin depending on the field of action. This systematic colouring of the skin of Egyptian gods is obviously also the reason why Ptolemaic workshops gave Serapis a dark skin colour.

35. When we talk about the successful artists of European Antiquity, we have to remember that we are dealing with large workshops led by and named after a leading master. The output of these workshops is highly productive -1500 bronze sculptures were accomplished in the Lysipp factory alone - and demands a precise division of labour with a high degree of specialisation, which distinguishes between the trades (see Plutarch, Pericles 12.6; Der Neue Overbeck 934 ), but also between the motifs. We meet the gilder, the engraver, the static engineer, the founder, the chaser in the sculptor's 
workshop, but certainly also the ornament painter, the animal painter, etc. in the large painters' factories. It has been proven that there have been times when specialists have been lent out between the large companies and cooperation has been sought. The famous passage at Pliny (NH 35.133), which reports that the renowned painter's workshop of Nikias took over the colouring of some marble sculptures from the production of the sculptor's workshop of Praxiteles, is no exception. For this purpose, specialists were probably lent out, whereby Nikias personally conceived and supervised the colouring of the figures of Praxiteles and also put his hands on them. (see Pausanias 1.28.2: Phidias and Parrhasiois cooperating; Phidias cooperating with Panainos: Strabon 8.3.30).

In his witty writing about animals, Aelian often lets the view of the ancient authors have their say. In the epilogue (De natura animalium, 17, Epilogos; Der Neue Overbeck 2934), he finally asks himself about the attitude of the painters who specialized in depicting animals and who received commissions in the famous painting companies (Aglaophon and Apelles) as well as in the sculptor's workshops (Myron) to contribute their special skills. The cow of Myron became extremely famous in Antiquity because of the amazing trueness to life which had been achieved through the use of form and colour. In fact, the design of the deceptively real fur of the Myron cow is emphasized in the ancient epigrams. These animal painters, who were obviously specialized in the reproduction of fur, were, according to Aelian, also proud when their contribution was accepted and valued by the great masters: "How do the people think who are specialized in the painterly reproduction $<$ of animals $>[\ldots$.$] ? They are <$ justly $>$ proud of themselves, because not only a horse, which they perfectly painted, convinced even an Aglaophon, but also a <perfectly painted $>$ deer calf, even an Apelles, as well as $<$ their colouring of a $>$ plastically modelled young cow, even a Myron." (trans. V. Brinkmann). And see Anthologia Graeca 9.717 (MMD 726/ Der Neue Overbeck 769): "Either the entire bronze coat is laid on this cattle, or the bronze has life inside it."

36. http://www.noack-bronze.com/de/ oberflaechenveredelung.html

37. Inscriptiones Graecae $\mathrm{I}^{3}, 435$ line 79 (Der Neue Overbeck 870).

38. "The open, high neck offered an irresistibly delightful spectacle. The bronze was modified so precisely, obeying the demand for faithful imitation of nature (mimesis) in every detail, that even her lips gave the impression that if you wanted to wait a little, you would hear a lovely voice. The pulsation of the veins was also imitated, and the whole body bent as if it were soft where it was right, and although it had no life, it still had its eyes full of the desire for love, as if it lived in the blooming youth." (Niketas Choniatès, Historia, p. 558,47559,77 van Dieten; translated V. Brinkmann; cf. MMD 814/Der Neue Overbeck 880). The deceptive liveliness of Classical and Hellenistic works of art is celebrated above all in the ancient literary genre of epigrams. A well-known instance is the bronze statue of a young cow from Myron: MMD 701/Der Neue Overbeck 753, 767-816; see also note 45 in Évelyne Prioux, "Materiae non cedit opus. Matières et sujets dans les épigrammes descriptives (III ${ }^{\mathrm{e}}$ siècle av. J.-C.-50 après J.-C.)", in Rouveret, Dubel, Naas, 2006, p. $127-160$.

39. Hughes, Rowe, 1991, p. 351-352. Lustre colours have a transparent quality, which is not due to an inherent colour of a layer formed at the surface of the metal, but to thin layers deposited on the surface of the metal as optical interference colours.

40. Niketas Choniatès (Historia $\mathrm{p}$. 558.47-559.77 van Dieten, MMD 814/Der Neue Overbeck 880) describes the Aegis of Athena with the words "poikilon aigidodes endyma", thus the "colorful goat-like robe". MMD translates correctly, while Der Neue Overbeck translates misleadingly "artfully chased, goatskin-like cape". Obviously, the author of The New Overbeck 880 as well as numerous other philologists were not able to imagine that a bronze sculpture was designed in many colours due to their classicist influence. However, Hesiod, for example, provides a verbose description of the colours of the shield of Heracles. Thus he mentions blue smalt, ivory inlays, copper (chalkós), silver, gold and steel (?adámas), blood-dyed dark red fabric (159), dotted dark blue dragon backs, black pine (Hesiod, scutum 166-167), black blood (Hesiod, scutum 173-174), purple blood (Hesiod, scutum 194), white teeth (Hesiod, scutum 249), pale green death (Hesiod, scutum 265), white and black vines (Hesiod, scutum 294), etc. Hesiod describes a fictitious object, but with elements that are executed in real craftsmanship (damascening, artificial patination, lustre technique? on gold/silver plating) that are totally plausible for the reader. (See for the ekphrasis debate: Niels Koopmann, Ancient Greek Ekphrasis. Between Description and Narration, 2018); S. Altekamp, "Zu den Statuenbeschreibungen des Kallistratos”, Boreas 11 (1988) p. 77-154; O. Primavesi, L. Giuliani, "Bild und rede: On the Proömium of the 'Eikones' of the Second Philostrat", Poetica 44, No. $1 / 2$ (2012), p. 25-79; S. Dubel, "Quand la matière est couleur. Du bouclier d'Achille aux 'tableaux de bronze' de Taxila" in Rouveret, Dubel, Naas, 2006, p. 161-181; S. Dubel, "Aphrodite se mirant au bouclier d'Arès. Transpositions homériques et jeux de matière dans l'epos hellénistique", in É. Prioux, A. Rouveret (eds.), Métamorphoses du Regard Ancien (2010), p. 13-28).

41. On the various ancient methods of silver plating, see: Gunther Kraft, ChemischAnalytische Charakterisierung römischer Silbermünzen, Diss. Technische Universität Darmstadt 2005, p. 14-21 (http://tuprints. ulb.tu-darmstadt.de/epda/000609/

KraftGunther_01.pdf_01.pdf).

See silver foil or mercury silvering on Roman mask-helmets (silver foil: Kalkriese: N. Hanel, S. Wilbers-Rost, F. Willer: "Die Helmmaske von Kalkriese", in Bonner Jahrbücher 204, 2004, p. 71-91; silver in amalgam technique: mask from a helmet found in Birkenfeld-Gräfenhausen, Limesmuseum Aalen). See also Pliny, NH 34.162 (silvering in Ancient Alesia).

42. See silver foot nails on a Egyptian bronze statue of priestess Takusit in the National Museum of Athens (inv. 110). Silver nails in Ancient Greek and Roman

Literature: Henke, in press.

43. Georg Treu,"Bemalter Marmorkopf im British Museum", Jahrbuch des Kaiserlichen Deutschen Archäologischen Institutes 4, 1889,

p. 18-24; G. Verri, T. Opper, T. Deviese, "The 'Treu Head': A Case Study in Roman Sculptural Polychromy", The British Museum Technical Research Bulletin 4, 2010, p. 39-54;

U. Koch-Brinkmann, V. Brinkmann, H.

Piening, "On the Rendering of Human Skin in Ancient Marble Sculpture", in J. S.

Østergaard, A. M. Nielsen (eds.),

Transformations. Classical Sculpture in Colour,

Ny Carlsberg Glyptotek, Copenhagen, 2014, p. $140-150$.

44. Inscriptiones Graecae $\mathrm{I}^{3}, 435$ line 105-

106 (Der Neue Overbeck 870). Gilding.

45. https://en.m.wikipedia.org/wiki/

\section{Bibliography}

Bol P. C., 1985, Antike Bronzetechnik. Kunst und Handwerk antiker Erzbildner, Beck's Archäologische Bibliothek, München.

Born H., 1993, "Multi-coloured antique bronze statues", in S. La-Niece, P. Craddock (eds.), Metal Plating and Patination. Cultural, Technical and Historical Development, ButterworthHeinemann, Oxford, p. 19-29.

Brinkmann V., 1987, "La polychromie de la sculpture archaïque en marbre", Pact 17, p. 35 sqq.

Brinkmann V., 1994, Beobachtungen zum formalen Aufbau und zum Sinngehalt der Friese des Siphnierschatzshauses, Biering \& Brinkmann, München.

Brinkmann V., 2003, Die Polychromie der archaischen und frühklassischen Skulptur, Biering \& Brinkmann, München.

Brinkmann V., 2015, "Art of Many Colors: Classical Statues in their Original Appearance", in S. Settis, A. Anguissola, D. Gasparotto (eds.), Serial/Portable Classic: Multiplying Art in Greece and Rome, Fondazione Prada, Milano, p. 95-100.

Brinkmann V., Dreyfus R., Koch-Brinkmann U. (eds.), 2017, Gods in Color, exhibition catalogue, Fine Arts Museums of San Francisco, DelMonico Books, New York.

Brinkmann V., Koch-Brinkmann U., 2016, "Das Rätsel der Bronzekrieger aus Riace", in Vinzenz Brinkmann (ed.), Athen: Triumph der Bilder, exhibition catalogue Liebieghaus Skulpturensammlung, Frankfurt am Main, p. 114-125.

Brinkmann V., Koch-Brinkmann U., 2017, "On the Polychromy of Ancient Sculpture: The Riace Warriors", in Brinkmann, Dreyfus, Koch-Brinkmann (eds.), 2017, p. 40-44.

Brinkmann V., Koch-Brinkmann U., 2018a, "The Riace Bronzes Experiment, 
Aesthetics and Narrative", in Ahoros, Gedenkschrift für Hugo Mever von Weggefährten, Kollegen und Freunden, Wien, p. 15-34

Brinkmann V., Koch-Brinkmann U., 2018b, "Die sogenannten Quirinalsbronzen und der Faustkampf von Amykos mit dem Argonauten Polydeukes. Ein archäologisches Experiment", in V. Brinkmann (dir.), Medeas Liebe und die Jagd nach dem goldenen Vlies, exhibition catalogue Liebieghaus Skulpturensammlung, Frankfurt am Main, Hirmer Verlag, München, p. 80-97.

Colacicchi Alessandri O., Ferretti M., 2018, "Technische Untersuchung der beiden Grossbronzen im Museo Nazionale Romano" in V. Brinkmann (dir.), Medeas Liebe und die Jagd nach dem goldenen Vlies, exhibition catalogue Liebieghaus Skulpturensammlung, Frankfurt am Main, Hirmer Verlag, München, p. 98-111.

Craddock P., Giumlia-Mair A. R., 1993, "Beauty is skin deep: evidence for the original appearance of classical statuary", in S. La-Niece, P. Craddock (eds.), Metal Plating and Patination. Cultural, Technical and Historical Development, Butterworth-Heinemann, Oxford, p. 30-38.

Descamps-Lequime S., 2006, "La polychromie des bronzes grecs et romains", in A. Rouveret, S. Dubel, V. Naas (eds.), Couleurs et matières dans l'Antiquité. Textes, techniques et pratiques (Études de Littérature Ancienne 17), Éditions rue d'Ulm, Paris, p. 79-92.

Descamps-Lequime S., Mille B. (eds.), 2017, Bronzes grecs et romains : études récentes sur la statuaire antique, Technè $\mathrm{n}^{\circ} 45$.

Dontas G., 1984, "Considerazioni sui bronzi di Riace. Proposte sui maestri e sulla provenienza delle statue", in Triches G. (ed.), Due bronzi da Riace. Rinvenimento, restauro, analisi ed ipotesi di interpretazione, Serie speciale, Bollettino d'Arte, 1-3, p. 277-296.

Formigli E., 2013, "Die Oberflächengestaltung antiker Großbronzen", in V. Brinkmann (ed.), Zurück zur Klassik. Ein neuer Blick auf das alte Griechenland, exhibition catalogue Liebieghaus Skulpturensammlung, Frankfurt am Main, p. 274-306.

Giuliano A., 1981, "I grandi bronzi di Riace", Xenia 2, p. 55-60.

Giumlia-Mair A. R., 2002, "Zosimos

The Alchemist - Manuscript 6.29, Cambridge, Metallurgical interpretation", in Giumlia-Mair A. R. (ed.), I Bronzi antichi. Produzione e tecnologia. Atti del XV Congresso internazionale sui bronzi antichi (GradoAquileia, 2-26 maggio 2001), Monographies instrumentum 21, éditions Monique Mergoil, Montagnac, p. 317323.

Guzzo P. G., 1981, "Riace, Firenze, Reggio Calabria. L'avventura dei 'bronzi'”, Rivista Storica Calabrese 2, p. 219-225.

Henke F. M., in print, Graptoi Typoi. Die griechischen und lateinischen Schriftquellen zur Farbigkeit der antiken Skulptur (Diss. Ludwig Maximilians-Universität Munich, 2014).

Hughes R., 1993, "Artificial Patination", in S. La-Niece, P. Craddock (eds.), Metal Plating and Patination. Cultural, Technical and Historical Development, ButterworthHeinemann, Oxford, p. 1-18.

Hughes R., Rowe M., 1991, The Colouring, Bronzing and Patination of Metals, Watson-Guptill, London.

Mattusch C. C., 1996, "The Preferred Medium: The Many Lives of Classical Bronzes", in C. C. Mattusch (ed.), The Fire of Hephaistos, Large Classical Bronzes from North American Collections, Harvard University Art Museums, CambridgeMA, p. 26-28.

Melucco Vaccaro A., de Palma G., de Micheli M., Vidale M. (eds.), 2003, I Bronzi di
Riace : restauro come conoscenza, Istituto Centrale per il Restauro, Artemide Edizioni, Roma

Muller-Dufeu M., 2006, "Les couleurs du bronze dans les statues grecques d'après les descriptions antiques", in A. Rouveret, S. Dubel, V. Naas (eds.) Couleurs et matières dans l'Antiquité. Textes, techniques et pratiques (Etudes de Littérature Ancienne 17), Éditions rue d'Ulm, Paris, p. 93-122.

Orazi N., Paolini S., Zammit U., Caruso G., Mercuri F., 2018, "Thermographische Untersuchungen am 'Faustkämpfer' und am 'Thermenherrscher'", in V. Brinkmann (dir.), Medeas Liebe und die Jagd nach dem goldenen Vlies, exhibition catalogue Liebieghaus

Skulpturensammlung, Frankfurt am Main, p. 112-115.

Orazi N., Mercuri F., Zammit U., Cicero C., Colacicchi Alessandri O., Brinkmann V., Caruso G., Ferretti M., Paoloni S., 2019, "The "Boxer at Res' and the 'Hellenistic Prince': A comparative thermographic study", Journal of Archaeological Science, Reports 24, p. 115121.

Paoletti M., Settis S. (eds.), 2015, Sul Buono e sul Cattivo Uso dei Bronzi di Riace, Donzelli Editore, Roma.

Rouveret A., Dubel S., Naas V. (eds.), 2006, Couleurs et matières dans l'Antiquité. Textes, techniques et pratiques (Etudes de Littérature Ancienne 17), Éditions rue d'Ulm, Paris.

Triches G. (ed.), 1984, "Due bronzi da Riace. Rinvenimento, restauro, analisi ed ipotesi di interpretazione", Serie speciale, Bollettino d'Arte, 1-3.

Willer F., 1994, "Fragen zur intentionalen Schwarzpatina an den Mahdiabronzen", in G. Hellenkemper Salies, H.-H. von Prittwitz und Gaffron, G. Bauchhen $\beta$ (eds.), Das Wrack. Der antike Schiffsfund von Mahdia, Exhibition catalog Bonn, Rheinisches Landesmuseum, Bonn. 